\title{
ANALISIS BAHAN AJAR PADA MATA KULIAH KALKULUS LANJUT
}

\author{
Nurul Farida ${ }^{1)}$, Rina Agustina ${ }^{2)}$ \\ ${ }^{1), 2)}$ Fakultas Keguruan dan Ilmu Pendidikan, Universitas Muhammadiyah Metro \\ Email: nurulfaridamath@gmail.com ${ }^{1)}$, aasyiqun1212@gmail.com ${ }^{2)}$
}

\begin{abstract}
Teaching materials are learning resources in the form of materials or materials arranged systematically to help educators in learning so that learners are able to master the competence to be achieved. Based on the results of prasurvey obtained results that not yet available teaching materials that are able to facilitate, find, and develop mathematical concepts in advanced calculus course. Inquiry is a learning activity that emphasizes the critical thinking process and analysis to find and solve the problems until get a conclusion.This study aims to analyze the process of preparing the teaching material based inqury in Advanced Calculus course. The results obtained from this study are the teaching material based inqury in Advanced Calculus course which received an average validation score of $63 \%$ in the eligible categories of language, instructional design, and materials, and it can be implementation in advanced calculus learning.
\end{abstract}

Keywords: advanced calculus, instructional materials, inquiry

\section{PENDAHULUAN}

Kalkulus Lanjut merupakan mata kuliah wajib bagi mahasiswa pendidikan matematika di perguruan tinggi. Di Pendidikan Matematika Universitas Muhammadiyah Metro, mata kuliah kalkulus lanjut merupakan lanjutan kalkulus I dan kalkulus II. Materi dalam kalkulus lanjut meliputi turunan tingkat tinggi dan integral lipat. Untuk dapat menguasai konsep yang ada pada materi tersebut, mahasiswa dituntut untuk dapat mengembangkan kamampuan berpikirnya, karena kemampuan pemahaman konsep yang baik dapat memudahkan mahasiswa dalam memahami konsep baru pada materi-materi ataupun pembelajaran matematika yang memiliki tingkat abstraksi yang lebih tinggi. Dengan tingkat abstraksi yang tinggi maka diperlukan bahan ajar yang dapat membantu mahasiswa mengkonstuksi sendiri pengetahuan yang telah diperoleh sebelumnya.

Pembelajaran yang dapat membuat peserta didik menemukan sendiri suatu konsep salah satunya dengan pembelajaran berbasis inkuiri. Inkuiri adalah salah satu cara belajar yang bersifat mencari pemecahan masalah dengan cara kritis, analisis, dan ilmiah dengan menggunakan langkahlangkah tertentu menuju kesimpulan yang meyakinkan karena didukung oleh data (Hamdani, 2011: 182). Lebih lanjut Hamdani (2011:23) mengungkapkan bahwa ciri khas pembelajaran inkuiri adalah adanya bimbingan, latihan, dan pembiasaan untuk terampil berpikir karena peserta didik terlibat secara mental dan fisik karena peserta didik diberikan kesempatan untuk mengungkapkan gagasan sesuai dengan pengetahuan awal yang dimiliki. Selanjutnya Bell (1981: 140) mengungkapkan bahwa Inquiry 
processes are used in science and mathematics to extend and organize knowledge". Berdasarkan penelitian Suwondo \& Wulandari (2013), pembelajaran berbasis inkuiri dapat meningkatkan prestasi akademik peserta didik pada tingkat universitas. Sejalan dengan pembelajaran berbasis inkuiri yang mampu meningkatkan pemahaman konsep, diperlukan juga berbagai sumber belajar yang dapat menunjang kelancaran dalam pembelajaran. Sumber belajar yang dapat digunakan yakni bahan ajar. Menurut Hamdani (2011: 120), bahan ajar merupakan sumber belajar yang berbentuk bahan atau materi yang tersusun secara sistematis untuk membantu pendidik dalam pembelajaran sehingga peserta didik mampu menguasai kompetensi secara utuh. Menurut Oladejo, et al (2011), bahan ajar ada di berbagai kelas, seperti audio, visual, atau audiovisual. Bahan ajar audio yang merujuk kepada orang atau perangkat yang memanfaatkan indera pendengaran saja, seperti radio, tape rekaman audio, dan televisi. Bahan visual instruksional lainnya adalah perangkat berkaitan dengan indra penglihatan seperti papan tulis, grafik, slide, dan film strip. Lebih lanjut Cakir (2015) mengungkapkan bahwa bahan ajar dapat dikategorikan dalam tiga kelompok yaitu: 1) bahan tradisional, 2) materi audio dan visual, dan 3) materi berbasis teknologi komunikasi informasi (TIK). Materi tradisional seperti buku pelajaran, lembar kerja, grafik, bahan ajar guru, dll. Sedangkan untuk materi audio dan visual seperti video pemutar, bahan audio, kamera video, komputer, perangkat proyeksi, dan sebagainya. Kategori ketiga untuk bahan ajar adalah materi berbasis TIK.

Dalam menyusun bahan ajar perlu memperhatikan prinsip-prinsipnya. Menurut Direktorat Pembinaan SMA
(2010) prinsip-prinsip pemilihan bahan ajar meliputi: (a) prinsip relevansi yaitu kesesuaian materi dengan tujuan yang ingin dicapai, (b) prinsip konsistensi yaitu keajegan, dan (c) prinsip kecukupan yaitu harus memadai dan membantu peserta didik dalam menguasai materi yang diajarkan. Lebih lanjut dalam Depdiknas (2008) bahwa pengembangan bahan ajar harus dapat menjawab atau memecahkan masalah ataupun kesulitan dalam belajar. Terdapat sejumlah materi pembelajaran yang seringkali peserta didik sulit untuk memahaminya. Kesulitan tersebut dapat saja terjadi karena materi tersebut memiliki tingkat abstraksi yang tinggi.

Berdasarkan analisis masalah perlu menyusun bahan ajar yang dapat disesuaikan dengan kemampuan peserta didik. Belum adanya ketersediaan bahan ajar yang mampu membuat mahasiswa mampu menemukan dan mengembangkan konsep matematika dalam perkuliahan kalkulus lanjut menjadi dasar perlu dilakukan penelitian mengenai analisis proses penyusunan bahan ajar kalkulus lanjut berbasis inkuiri.

\section{METODE PENELITIAN}

Penyusunan bahan ajar berbasis inkuiri meliputi beberapa tahapan, yaitu merencanakan penyusunan bahan ajar, menyusun bahan bahan ajar, validasi oleh ahli, merevisi bahan ajar, menghasilkan produk bahan ajar. Tahap validasi dalam penelitian ini dilakukan oleh tiga orang validator yang meliputi ahli materi, ahli desain, dan ahli bahasa. Pengumpulan data dalam penelitian ini menggunakan angket. Instrumen yang digunakan dalam penelitian ini adalah lembar angket. Data yang digunakan dalam penelitian ini berupa data kualitatif. 


\section{HASIL DAN PEMBAHASAN}

Berdasarkan penelitian yang telah dilaksanakan diperoleh hasil sebagai berikut.

Tahap pertama yang dilakukan adalah merencanakan penyusunan bahan ajar dengan terlebih dahulu mengumpulkan informasi mengenai kebutuhan bahan ajar mata kuliah kalkulus lanjut dengan cara menyebar angket kepada mahasiswa yang pernah mengikuti pembelajaran kalkulus lanjut. Dari hasil angket yang diisi oleh 43 mahasiswa secara umum diperoleh data tentang kondisi bahan ajar bagi mahasiswa yang mengikuti pembelajaran kalkulus lanjut sebagai berikut:

1. Dalam pembelajaran
lanjut, mahasiswa
menggunakan satu
pegangan.

2. Buku pegangan yang digunakan belum bisa membantu mahasiswa dalam mempelajari kalkulus lanjut.

3. Buku pegangan yang digunakan belum menambah minat mahasiswa dalam mempelajari kalkulus lanjut.

4. Kalimat pada buku pegangan sulit dipahami.

5. Mahasiswa merasa membutuhkan buku pegangan yang dapat membantu dan menambah minat dalam mempelajari kalkulus lanjut.

6. Mahasiswa merasa membutuhkan buku pegangan yang berisikan soal-soal dan pembahasan untuk meningkatkan pemahaman konsep kalkulus lanjut.

Berdasarkan hasil angket diperoleh bahwa perlunya penyusunan bahan ajar untuk meningkatkan pemahaman konsep mahasiswa mencapai $97,67 \%$ dari 43 mahasiswa yang dijadikan responden. Setelah dilakukan analisis kebutuhan bahan ajar, selanjutnya dilakukan analisis terhadap materi kalkulus lanjut. Materi pada bahan ajar kalkulus lanjut dibatasi menjadi enam bab yang terdiri dari 1) parabola, elips, hiperbola, 2) translasi sumbu, rotasi sumbu, 3) vektor pada bidang, 4) koordinat kartesius dan vektor dalam ruang berdimensi tiga, 5) garis dan kurva dalam ruang berdimensi tiga, dan 6) permukaan dalam ruang berdimensi tiga.

Tahap kedua adalah menyusun bahan ajar berbasis berbasis inkuiri pada mata kuliah kalkulus lanjut. Bahan ajar kalkulus lanjut berbasis inkuiri dalam penelitian ini terdiri dari 1) mendefinisikan masalah, 2) merumuskan hipotesis, 3) mengumpulkan dan menganalisis data, dan 6) membuat kesimpulan. Bahan ajar kalkulus lanjut yang telah disusun selanjutnya dilakukan penilaian oleh tim validator. Tim validator terdiri dari tiga orang ahli yaitu ahli materi, ahli bahasa, dan ahli desain pembelajaran. Dalam penelitian ini validasi ini dilakukan oleh 3 orang validator, yaitu (1) Nurain Suryadinata, M.Pd. Dosen Pendidikan Matematika Universitas Muhammadiyah Metro sebagai ahli materi, (2) Rosida Rakhmawati, M. Pd. Dosen Pendidikan Matematika UIN Raden Intan Lampung sebagai ahli desain, dan (3) Sutrisni Andayani, M. Pd. Dosen Pendidikan Matematika Universitas Muhammadiyah Metro sebagai ahli bahasa. Hasil penilaian validator terhadap bahan ajar kalkulus lanjut berbasis inkuiri disajikan pada Tabel 1 berikut: 
ISSN 2089-8703 (Print) Vol. 6, No. 1 (2017)

ISSN 2442-5419 (Online)

Tabel 1. Hasil Validasi Bahan Ajar Kalkulus Lanjut

\begin{tabular}{|l|l|c|c|}
\hline No & \multicolumn{1}{|c|}{ Nama } & Nilai & Kategori \\
\hline 1. & Nurain Suryadinata. M.Pd. & $56 \%$ & Cukup Layak \\
\hline 2. & Rosida Rakhmawati, M. Pd. & $78 \%$ & Layak \\
\hline 3. & Sutrisni Andayani, M. Pd. & $56 \%$ & Cukup Layak \\
\hline \multicolumn{2}{|c|}{ RATA-RATA } & $\mathbf{6 3 \%}$ & Layak \\
\hline
\end{tabular}

Berdasarkan Tabel 1 diperoleh nilai rata-rata dari ketiga validator sebesar $63 \%$. Dengan demikian bahan ajar kalkulus lanjut berbasis inkuiri yang disusun memenuhi kriteria layak untuk digunakan dalam pembelajaran. Namun demikian bahan ajar kalkulus lanjut yang disusun masih perlu dilakukan perbaikan. Perbaikan dilakukan berdasarkan saran dan komentar dari validator. Dari validator 1 sebagai ahli materi terdapat perbaikan yaitu adanya soal yang dapat membingungkan mahasiswa sehingga perlu dilakukan revisi soal. Selain itu, pada soal perlu ditambahkan penambahan soal pada bagian latihan sehingga mahasiswa dapat terbiasa untuk menyelesaikan soal pemahaman konsep. Dari ahli desain dan bahasa, didapatkan perbaikan hanya terletak pada tata tulis dan kalimat yang dapat memunculkan makna ganda (ambigu).

Berdasarkan saran dan komentar dari validator selanjutnya dilakukan revisi terhadap bahan ajar kalkulus lanjut yang disusun. Hasil revisi bahan ajar disajikan pada Tabel 2 berikut:

Tabel 2. Bahan Ajar Sebelum dan Sesudah Perbaikan

\begin{tabular}{|c|c|c|}
\hline No & Sebelum & Sesudah \\
\hline \multirow[t]{2}{*}{1} & 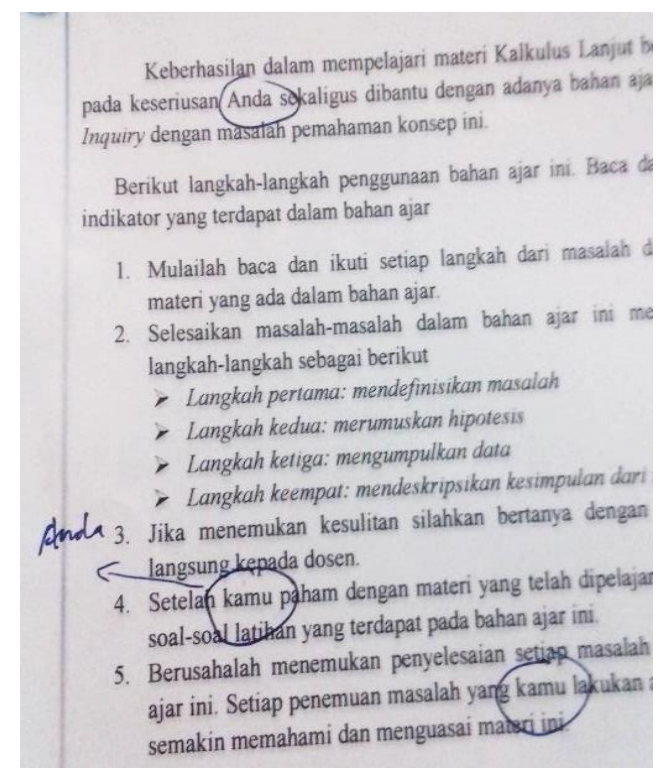 & $\begin{array}{l}\text { Keberhasilan Anda dalam mempelajari materi ini bergantung pada } \\
\text { keseriusan Anda sekaligus dibantu dengan adanya bahan ajar berbasis } \\
\text { Inquiry dengan masalah pemahaman konsepini. } \\
\text { Berikut langkah-langkah penggunaan bahan ajar ini. Baca dan pahami } \\
\text { indikator yang terdapat dalam bahan ajar } \\
\text { 1. Mulailah baca dan ikuti setiap langkah dari masalah dan konsep } \\
\text { materi yang ada dalam bahan ajar. } \\
\text { 2. Selesaikan masalah-masalah dalam bahan ajar ini menggunakan } \\
\text { langkah-langkah sebagai berikut } \\
\text { Langkah pertama: mendefinisikan masalah } \\
\text { Langkah kedua: merumuskan hipotesis } \\
\text { Langkah ketiga: mengumpulkan data } \\
\text { Langkah keempat: mendesloipsikan kesimpulan dari masalah } \\
\text { 3. Jika menemukan kesulitan silahkan bertanya dengan teman atau } \\
\text { langsung kepada dosen. } \\
\text { 4. Setelah Anda paham dengan materi yang telah dipelajari kerjakanlah } \\
\text { soal-soal latihan yang terdapat pada bahan ajar ini. } \\
\text { 5. Berusahalah menemukan penyalesaian setiap masalah dalam bahan } \\
\text { ajar ini. Setiap penemuan masalah yang Anda lakukan akan membuat } \\
\text { semakin memahami dan menguasai materi ini. }\end{array}$ \\
\hline & Konsisten dalam menggunakan kata subjek & $\begin{array}{l}\text { Kata subjek yang sudah konsisten } \\
\text { menggunakan kata "Anda" }\end{array}$ \\
\hline
\end{tabular}




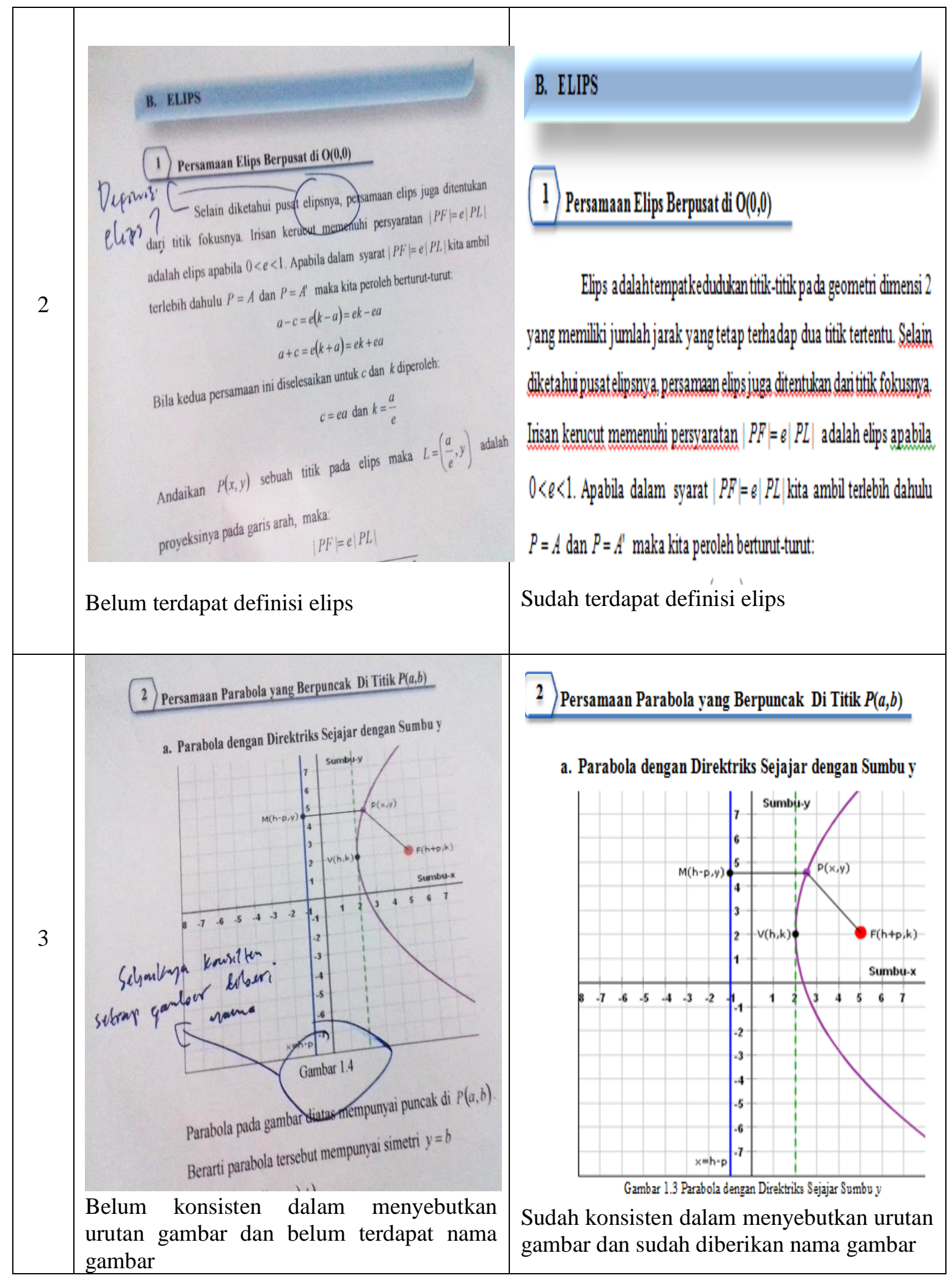


ISSN 2089-8703 (Print) Vol. 6, No. 1 (2017)

ISSN 2442-5419 (Online)

\begin{tabular}{|c|c|c|}
\hline 4 & 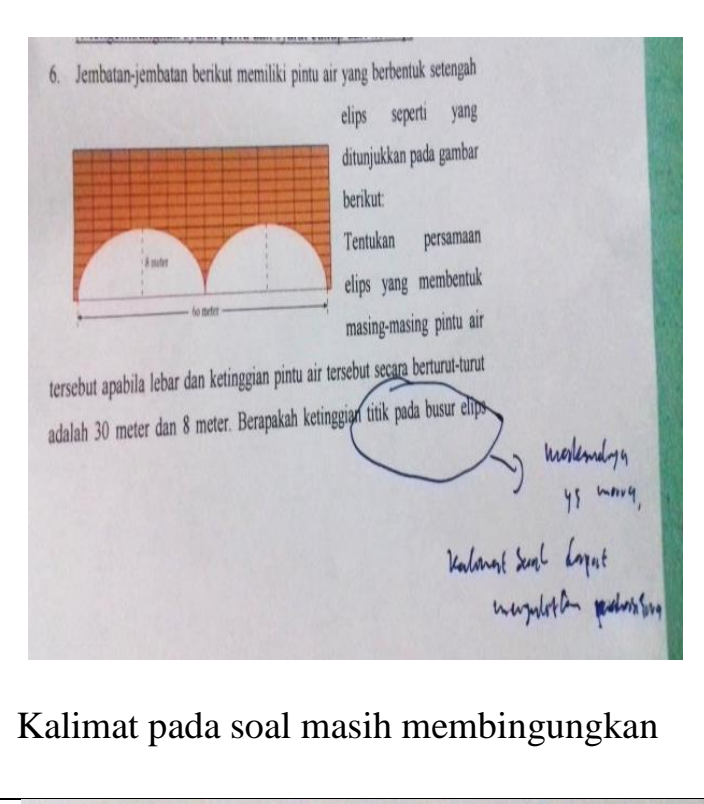 & $\begin{array}{l}\text { 6. Jembatan-jembatan berikut memiliki pintu air yang berbentuk setengah } \\
\text { elips seperti yang } \\
\text { ditunjulkkan pada gambar } \\
\text { berikut: } \\
\text { Tentukan persamaan } \\
\text { elips yang membentul } \\
\text { masing-masing pintu air } \\
\text { turut adalah } 30 \text { meter dan } 8 \text { meter. Berapakahh ketinggian titik pada elips } \\
\text { tersebut yang terletak } 9 \text { meter di kanan masing-masing titik pusat air } \\
\text { tersebut? Mengaplikasikan konsep atau algoritma pemecahan masaldh } \\
\text { Kalimat pada soal sudah diperbaiki menjadi } \\
\text { lebih sederhana }\end{array}$ \\
\hline 5 & 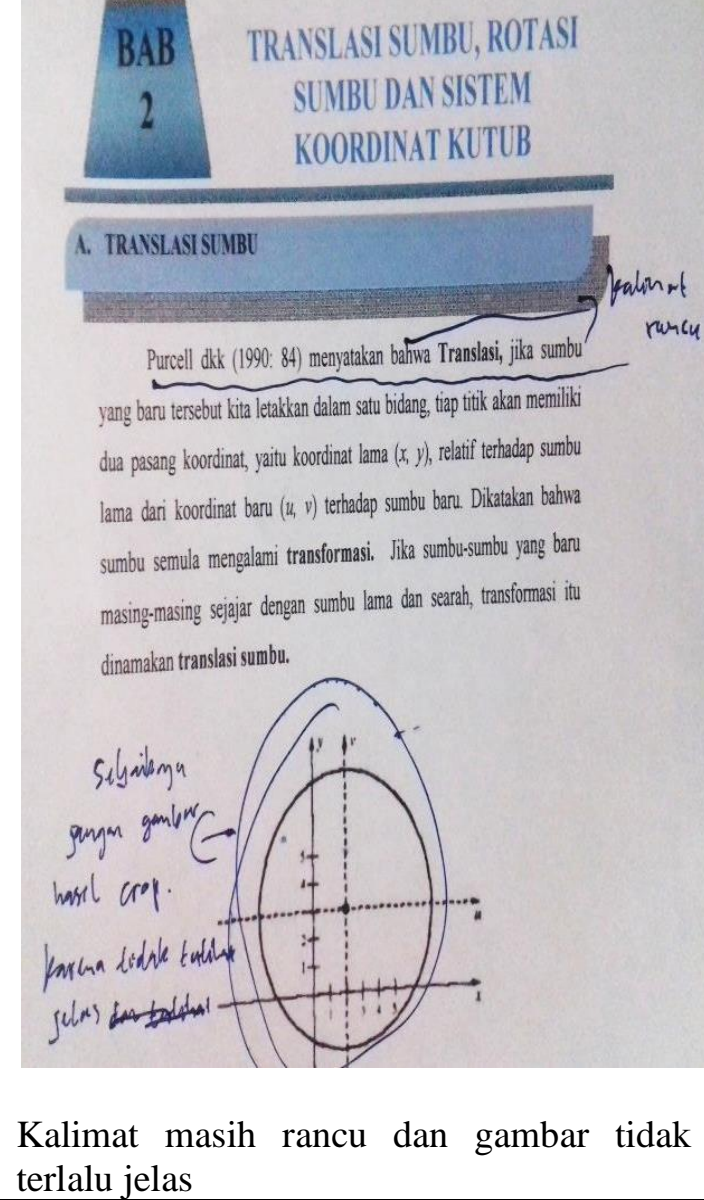 & 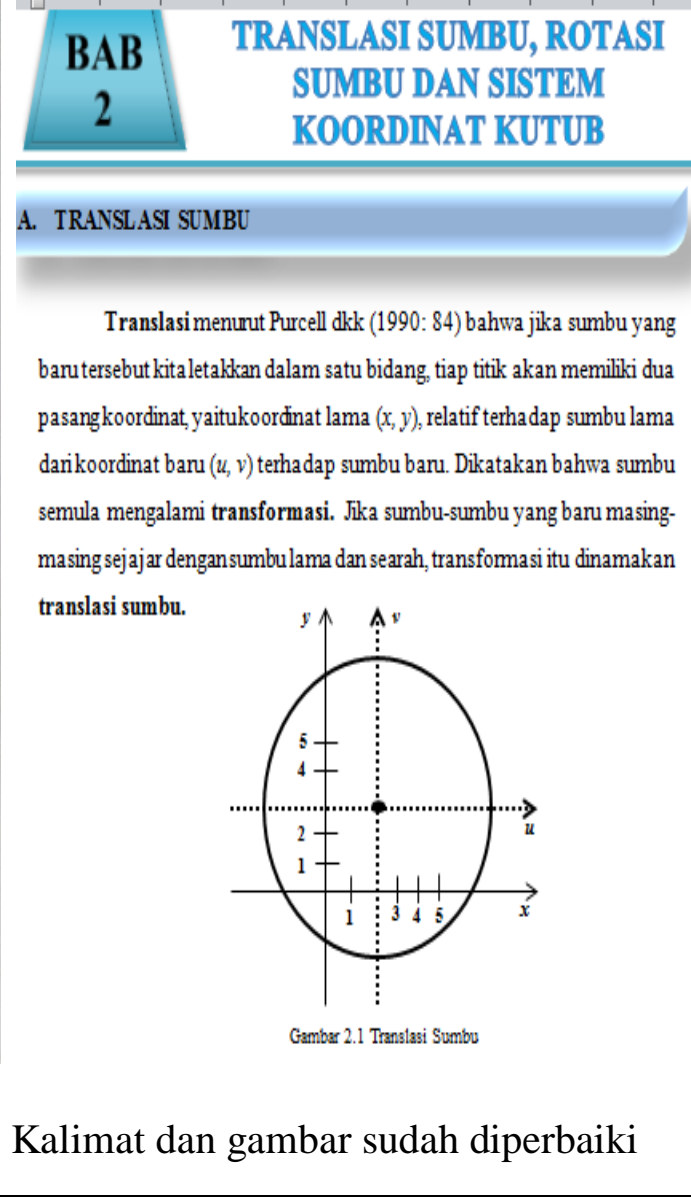 \\
\hline
\end{tabular}




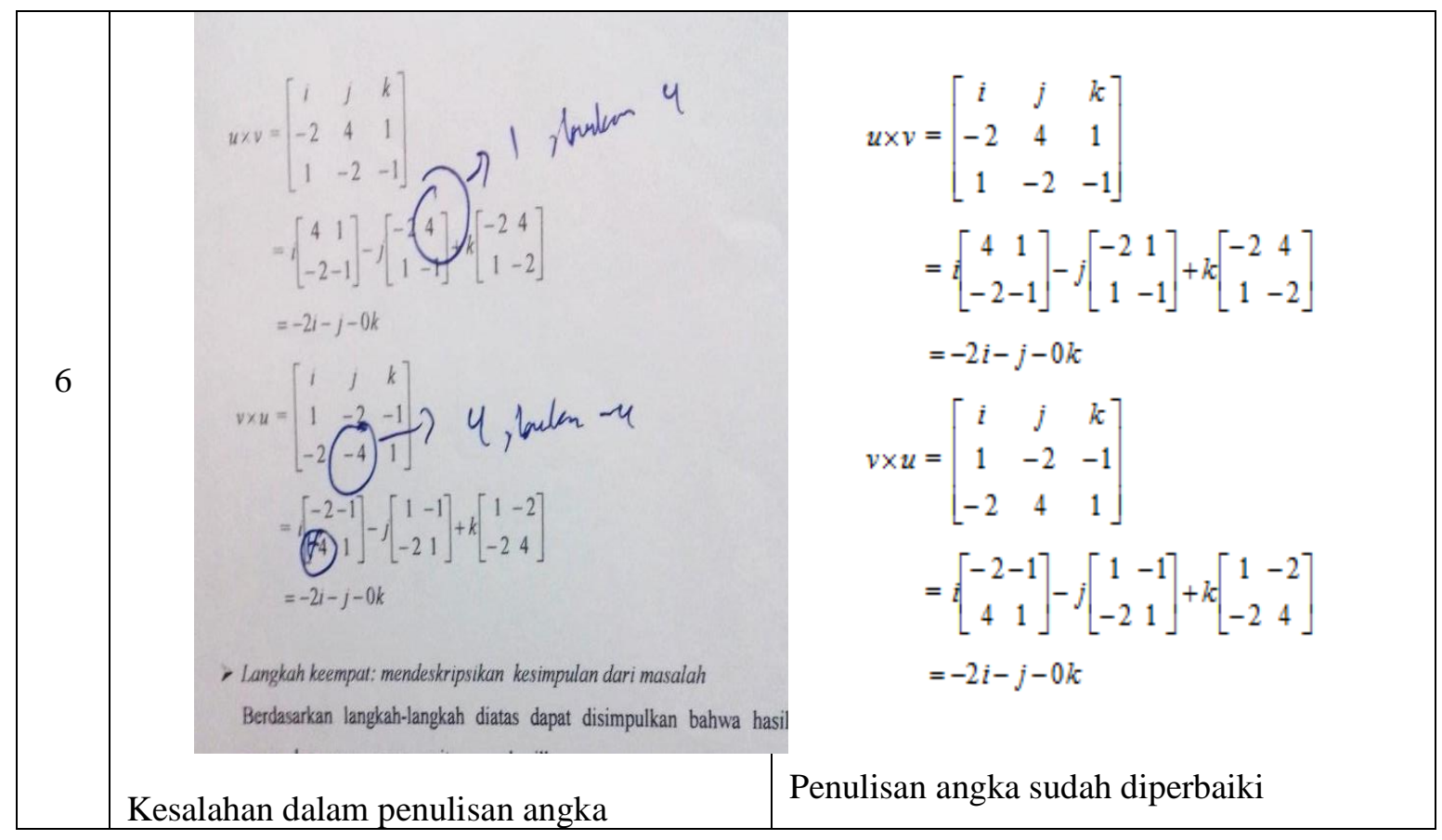

Berdasarkan hasil penelitian bahwa bahan ajar kalkulus lanjut berbasis inkuiri yang disusun telah dinyatakan layak untuk digunakan dalam pembelajaran. Bahan ajar kalkulus lanjut berbasis inkuiri ini membahas materi pada kalkulus lanjut dengan desain yang menarik, bahasa yang yang lebih mudah dipahami oleh mahasiswa. Selain itu dilengkapi dengan proses inkuiri dan soal-soal yang dapat membantu mahasiswa menemukan dan memunculkan konsep yang ada pada materi kalkulus lanjut. Berdasarkan penilaian dan revisi yang telah dilakukan, maka bahan ajar kalkulus lanjut yang disusun telah dinyatakan layak dan siap diimplementasikan dalam pembelajaran kalkulus lanjut.

\section{KESIMPULAN DAN SARAN}

Berdasarkan hasil dan pembahasan diperoleh kesimpulan sebagai berikut.

1. Perlu adanya bahan ajar yang dapat membantu mahasiswa dalam menemukan dan memudahkan mempelajari suatu konsep pada materi kalkulus lanjut.

2. Bahan ajar kalkulus lanjut berbasis inkuiri telah memenuhi krteria valid berdasarkan hasil validasi dari 3 orang validator. Bahan ajar ini memperoleh rata-rata nilai validasi sebesar $63 \%$ dalam kategori Layak. Bahan ajar berbasis inkuiri ini telah siap untuk digunakan dalam pembelajaran kalkulus lanjut.

Selanjutnya berdasarkan kesimpulan maka disarankan untuk dapat dilakukan implementasi terhadap bahan ajar kalkulus lanjut berbasis inkuiri yang telah disusun agar mengetahui efektifitas bahan ajar tersebut.

\section{DAFTAR PUSTAKA}

Bell, Frederick H. 1981. Teaching and Leraning Mathematics (In second School). United states of america : Wm. C.M Brown Company

Cakir, I. 2015. "Instructional Materials Commonly Employed by Foreign Language Teachers at Elementary 
ISSN 2089-8703 (Print) Vol. 6, No. 1 (2017)

ISSN 2442-5419 (Online)

Schools". International Electronic Journal of Elementary Education. Vol. 8. No.1. Hal. 69-82

Depdiknas. 2008. Panduan Pengembangan Bahan Ajar. Jakarta: Depdiknas.

Direktorat Pembinaan SMA. 2010. Juknis Pengembangan Bahan Ajar SMA.

Hamdani. 2011. Strategi Belajar Mengajar. Bandung: Pustaka Setia.

Oladejo, et al. 2011. "Instructional Materials and Students' Academic Achievement in Physics: Some Policy Implications". European Journal of Humanities and Social Sciences. Vol. 2. No.1 Hal 112 126.

Suwondo \& Wulandari, S. 2013. "InquiryBased Active Learning: The Enhancement of Attitude and Understanding of the Concept of Experimental Design in Biostatics Course". Asian Social Science. Vol. 9. No. 12. Hal 212-219. 